\title{
EKSPERIMENTASI PENDEKATAN PEMBELAJARAN RECIPROCAL TEACHING DENGAN ALAT PERAGA PADA POKOK BAHASAN LINGKARAN DITINJAU DARI KREATIVITAS SISWA
}

\author{
Faradila Thalib $^{1}$, Mardiyana ${ }^{2}$, Sutrima ${ }^{3}$ \\ ${ }^{1,2,3}$ Program Magister Pendidikan Matematika, PPs Universitas Sebelas Maret Surakarta
}

\begin{abstract}
This research aims at revealing:(1) which one results better learning achievement on the subject of circle among Reciprocal Teaching with Learning Tools, Reciprocal Teaching, and conventional approach; (2) which one has better mathematics learning achievement among students with high, average, or low creativity; (3) at each of creativity levels (high, average, and low), which one results better learning achievement on the subject of circle among Reciprocal Teaching with Learning Tools, Reciprocal Teaching, and conventional apprroach; (4) at each of teaching approaches (Reciprocal Teaching with Learning Tools, Reciprocal Teaching, and conventional approach), which group of students has better learning achievement among groups with high, average, or low creativity. This research was quasiexperimental research which employs $3 \times 3$ factorial design. The population of this research was all of the eleventh grade students of State Junior High Schools in Ternate. The sampling technique used was stratified cluster random sampling. There were 178 students selected as the sample of this research. Based on the research findings, it can be concluded that: (1) students taught by Reciprocal Teaching with Learning Tools have better mathematics learning achievement than those taught by Reciprocal Teaching, students taught by Reciprocal Teaching have better mathematics learning achievement than those taught by conventional approach, and students taught by Reciprocal Teaching have better mathematics learning achievement than those taught by conventional teaching; (2) students with high, average, and low creativity have the same mathematics learning achievement; (3) at each of creativity levels (high, average, and low), Reciprocal Teaching with Learning Tools results better mathematics learning achievement than Reciprocal Teaching and conventional approach do, and Reciprocal Teaching results better mathematics learning achievement than conventional approach does; (4) at each of teaching approaches (Reciprocal Teaching with Learning Tools, Reciprocal Teaching, and conventional approach), students with high, average, and low creativity have the same mathematics learning achievement.
\end{abstract}

Key words: Reciprocal Teaching with Learning Tools, Reciprocal Teaching, Conventional Approach, Creativity, Mathematics Learning Achievement.

\section{PENDAHULUAN}

Pendidikan adalah salah satu bentuk perwujudan kebudayaan manusia yang dinamis dan sarat perkembangan. Pendidikan yang mampu mendukung pembangunan di masa mendatang adalah pendidikan yang mampu mengembangkan potensi siswa, sehingga yang bersangkutan mampu menghadapi dan memecahkan problema kehidupan yang dihadapinya. Oleh karena itu, dalam proses pembelajaran guru harus benar-benar memperhatikan hal tersebut terutama pembelajaran matematika di sekolah yang merupakan prioritas dalam pembangunan pendidikan. Dalam proses pembelajaran, pemilihan pendekatan pembelajaran yang sesuai dengan materi merupakan salah satu hal yang sangat penting guna mencapai tujuan pembelajaran yang telah ditetapkan tersebut. Namun hingga saat ini sebagian besar guru dalam proses pembelajaran kerap kali yang 
digunakan adalah pendekatan pembelajaran konvensional. Hal ini yang menyebabkan siswa cenderung pasif sehingga tujuan pembelajaran tidak tercapai secara optimal dan berdampak pula pada prestasi belajar matematika yang dicapai siswa yang masih tergolong rendah. Data UN 2011 SMP yang bersumber dari Puspendik Kemendiknas (2011) menyebutkan bahwa dari 14 sekolah Negeri yang ada di Kota Ternate, nampak bahwa untuk mata pelajaran matematika masih terdapat 50 orang siswa dari 1950 orang peserta atau 2,56\% dari jumlah peserta Ujian Nasional yang masih memperoleh nilai di bawah standar nasional yaitu 5,50. Selain itu, dapat dilihat pada persentase penguasaan materi soal matematika Ujian Nasional 2011 SMP Negeri pada materi lingkaran perolehan persentase nilai siswa untuk tingkat propinsi hanya 69,64\% dan untuk tingkat nasional $65,44 \%$. Hal ini menerangkan masih perlunya usaha yang maksimal untuk meningkatkan prestasi belajar matematika siswa.

Menyadari kondisi tersebut, maka diperlukan adanya perubahan pola mengajar guru diantaranya adalah merubah pendekatan pembelajaran konvensional menjadi pendekatan pembelajaran yang bertujuan memperbaiki cara belajar siswa menjadi lebih aktif, kreatif, dan menyenangkan. Hasil penelitian Omari dan Wesha, (2010: 28) menjelaskan bahwa ada dasar untuk mengembangkan kemampuan dan mengaktifkan kembali pengetahuan siswa sebelumnya serta menggunakannya dalam situasi pembelajaran saat ini yaitu dengan menerapkan pembelajaran di mana ada pengalihan tanggung jawab dari guru ke siswa. Guru menjelaskan proses pemecahan masalah dan sekaligus mengurangi perannya. Terlepas dari itu, guru juga berasumsi bahwa siswa mampu dan akhirnya dapat melaksanakan proses pembelajaran secara mandiri. Hal ini menggambarkan bahwa proses belajar siswa harus diimbangi dengan penggunaan pendekatan pembelajaran yang sesuai. Menurut Rusman (2010: 132), pendekatan pembelajaran dapat diartikan sebagai titik tolak atau sudut pandang kita terhadap proses pembelajaran. Istilah pendekatan merujuk kepada pandangan tentang terjadinya suatu proses yang sifatnya masih sangat umum. Hal ini senada dengan Syaiful Sagala (2011: 68) yang menyatakan bahwa pendekatan pembelajaran merupakan jalan yang akan ditempuh oleh guru dan siswa dalam mencapai tujuan instruksional untuk suatu satuan instruksional tertentu. Pendekatan pembelajaran merupakan aktivitas yang dilakukan oleh guru untuk menjelaskan materi pelajaran dari bagian-bagian yang satu dengan bagian lainnya berorientasi pada pengalaman-pengalaman yang dimiliki siswa untuk mempelajari konsep, prinsip, atau teori yang baru tentang suatu bidang ilmu. Dalam kesempatan lain, Hamzah B. Uno (2011: 31) juga menyatakan bahwa pendekatan pembelajaran adalah bagaimana mengaktifkan keterlibatan siswa dalam proses 
pembelajaran secara mandiri, yaitu melalui kegiatan pembelajaran yang berorientasi pada penemuan (discovery) dan pencarian (inquiry).

Salah satu pendekatan yang digunakan adalah pendekatan Reciprocal Teaching dengan Alat Peraga. Pendekatan Reciprocal Teaching pertama kali diperkenalkan oleh Palincsar pada tahun 1982. Pendekatan pembelajaran Reciprocal teaching (pembelajaran terbalik) merupakan pendekatan terhadap pembelajaran siswa akan strategi-strategi belajar. Pembelajaran terbalik adalah pendekatan kontruktivis yang berdasar pada prinsipprinsip pembuatan/pengajuan pertanyaan, dimana keterampilan-keterampilan metakognitif diajarkan melalui pembelajaran langsung dan pemodelan oleh guru untuk memperbaiki kinerja membaca pemahaman yang rendah (Nur dalam Trianto, 2010: 173). Adapun empat komponen dalam pendekatan Reciprocal Teaching meliputi: Clarifying (mengklarifikasi), Predicting (memprediksi), Questioning (membuat soal/pertanyaan) serta Summarizing (merangkum). Sedangkan alat peraga adalah suatu alat yang dapat diserap oleh mata dan telinga dengan tujuan membantu guru agar proses belajar siswa lebih efektif dan efisien. Dalam penelitian Uyung Widi Rahayuningsih (2009) menyatakan bahwa dengan menggunakan alat peraga dalam pembelajaran maka akan lebih meningkatkan kemauan belajar siswa terhadap apa yang disampaikan. Alat peraga merupakan bagian dari media pembelajaran. Media pembelajaran terdiri dari dua suku kata yaitu media dan pembelajaran. Gerlach dan Ely (dalam Cecep Kustandi, dkk, 2011: 7) mengatakan, apabila dipahami secara garis besar, maka media adalah manusia, materi, atau kejadian yang membangun suatu kondisi atau membuat siswa mampu memperoleh pengetahuan, keterampilan, atau sikap.

Selain faktor pendekatan pembelajaran, kreativitas juga menentukan hasil belajar. Menurut teori kreativitas bahwa ketika para siswa bekerja bersama-sama untuk meraih sebuah tujuan kelompok, membuat mereka mengekspresikan norma-norma yang baik dalam melakukan apapun yang diperlukan untuk keberhasilan kelompok, sehingga pembelajaran menjadi sebuah aktivitas yang bisa membuat para siswa lebih unggul (Slavin, 2005: 35). Mengingat pentingnya kreativitas belajar siswa sebagai salah satu penunjang keberhasilan proses pendidikan, maka dalam kegiatan belajar mengajar diharapkan guru lebih banyak melibatkan kreativitas belajar siswa. Selain itu, siswa juga diharapkan dapat memotivasi dirinya sendiri untuk ikut aktif dan kreatif dalam kegiatan belajar mengajar. Dengan adanya kreativitas belajar ini kemungkinan besar peningkatan prestasi belajar akan tercapai.

Penelitian ini bertujuan untuk mengetahui: (1) manakah yang lebih baik, prestasi belajar siswa pada materi lingkaran menggunakan pendekatan pembelajaran Reciprocal Teaching dengan Alat Peraga, Reciprocal Teaching atau Konvensional, (2) manakah 
yang mempunyai prestasi belajar matematika lebih baik, siswa dengan kreativitas kategori tinggi, sedang atau rendah, (3) pada masing-masing kreativitas siswa (tinggi, sedang, dan rendah), manakah yang memberikan prestasi belajar matematika lebih baik, pendekatan pembelajaran Reciprocal Teaching dengan Alat Peraga, Reciprocal Teaching atau Konvensional, (4) pada masing-masing pendekatan pembelajaran (Reciprocal Teaching dengan Alat Peraga, Reciprocal Teaching, dan Konvensional), manakah yang memberikan prestasi belajar matematika lebih baik, kreativitas tinggi, sedang, atau rendah.

\section{METODE PENELITIAN}

Berdasarkan tujuan penelitian yang diteliti, maka jenis penelitian yang digunakan pada penelitian ini adalah penelitian eksperimental semu atau quasi experimental dengan desain 3x3 yang disajikan dalam tabel berikut.

Tabel 1. Rancangan Penelitian

\begin{tabular}{|c|c|c|c|}
\hline $\begin{array}{l}\text { Kreativitas Belajar }(B) \\
\text { Pendekatan } \\
\text { Pembelajaran }(A)\end{array}$ & $\begin{array}{c}\text { Tinggi } \\
\left(b_{1}\right)\end{array}$ & $\begin{array}{c}\text { Sedang } \\
\left(b_{2}\right)\end{array}$ & $\begin{array}{c}\text { Rendah } \\
\quad\left(b_{3}\right)\end{array}$ \\
\hline $\begin{array}{l}\text { Reciprocal Teaching dengan Alat Peraga }\left(a_{1}\right) \\
\text { Reciprocal Teaching }\left(a_{2}\right) \\
\text { Konvensional }\left(a_{3}\right)\end{array}$ & $\begin{array}{l}(a b)_{11} \\
(a b)_{21} \\
(a b)_{31}\end{array}$ & $\begin{array}{l}(a b)_{12} \\
(a b)_{22} \\
(a b)_{32}\end{array}$ & $\begin{array}{l}(a b)_{13} \\
(a b)_{23} \\
(a b)_{33}\end{array}$ \\
\hline
\end{tabular}

Populasi dalam penelitian ini adalah seluruh siswa SMP Negeri Kota Ternate. Sampel diambil secara acak dari SMP Negeri di Kota Ternate dengan teknik pengambilan stratified cluster random sampling, diperoleh SMP Negeri 3 Ternate mewakili kelompok tinggi, SMP Negeri 7 Ternate mewakili kelompok sedang, dan SMP Negeri 5 Ternate mewakili kelompok rendah.

Terdapat dua variabel dalam penelitian ini yakni variabel bebas yaitu pendekatan pembelajaran dan kreativitas belajar siswa, sedangkan variabel terikatnya yaitu prestasi belajar matematika siswa. Untuk mengumpulkan data digunakan metode tes, metode angket, dan metode dokumentasi. Metode tes digunakan untuk mengukur kemampuan siswa terhadap materi yang telah dipelajari dan mendapatkan data prestasi belajar matematika siswa. Data kreativitas siswa yang digolongkan menjadi tiga kategori yaitu kategori tinggi, sedang, dan rendah yang diperoleh dari angket, sedangkan metode dokumentasi digunakan untuk mengetahui kemampuan awal siswa yang diambil dari nilai ulangan harian.

Adapun teknik analisis data yang digunakan untuk menguji hipotesis dalam penelitian ini adalah analisis variansi dua jalan sel tak sama dengan banyaknya baris 3 dan banyaknya kolom 3. Sebelum masing-masing kelas diberikan perlakuan, terlebih 
dahulu dilakukan uji prasyarat terhadap data kemampuan awal siswa meliputi uji normalitas dengan menggunakan uji Liliefors dan uji homogenitas variansi menggunakan uji Barttlet. Selanjutnya dilakukan uji keseimbangan dengan analisis variansi satu jalan untuk mengetahui apakah kelas eksperimen dan kelas kontrol dalam keadaan seimbang atau tidak.

\section{HASIL PENELITIAN DAN PEMBAHASAN}

Berdasarkan hasil uji normalitas populasi terhadap data kemampuan awal matematika siswa, diperoleh simpulan bahwa sampel dari kelas eksperimen dan kelas kontrol berasal dari populasi yang berdistribusi normal. Demikian pula hasil uji homogenitas variansi populasi terhadap data kemampuan awal siswa, disimpulkan bahwa sampel berasal dari populasi-populasi yang homogen. Setelah dilakukan uji keseimbangan untuk mengetahui kemampuan awal masing-masing kelompok, diperoleh simpulan bahwa sampel dari kelas eksperimen dan kelas kontrol mempunyai kemampuan awal yang sama, selanjutnya dilakukan uji hipotesis penelitian.

Berikut ini disajikan rangkuman deskripsi rerata prestasi belajar matematika siswa berdasarkan kategori pendekatan pembelajaran yaitu pendekatan Reciprocal Teaching dengan Alat Peraga, Reciprocal Teaching, dan Konvensional ditinjau dari kreativitas siswa kategori tinggi, sedang, dan rendah.

Tabel 2. Deskripsi Rerata Prestasi Belajar Matematika Siswa pada Masing-Masing Pendekatan Pembelajaran dan Kreativitas

\begin{tabular}{|c|c|c|c|c|}
\hline $\begin{array}{l}\text { Pendekatan } \\
\text { Pembelajaran }(A)\end{array}$ & $\begin{array}{l}\text { Tinggi } \\
\left(b_{1}\right)\end{array}$ & $\begin{array}{l}\text { Sedang } \\
\left(b_{2}\right)\end{array}$ & $\begin{array}{l}\text { Rendah } \\
\left(b_{3}\right)\end{array}$ & $\begin{array}{c}\text { Rerata } \\
\text { Marginal }\end{array}$ \\
\hline Reciprocal Teaching Alat Peraga $\left(a_{1}\right)$ & 66,8335 & 66,0000 & 73,0000 & 67,4578 \\
\hline Reciprocal Teaching $\left(a_{2}\right)$ & 64,9132 & 57,0000 & 55,0000 & 58,9147 \\
\hline Konvensional $\left(a_{3}\right)$ & 47,0165 & 45,0000 & 38,4985 & 44,0000 \\
\hline Rerata Marginal & 59,0000 & 57,0000 & 53,0000 & \\
\hline
\end{tabular}

Tabel 3. Rangkuman Analisis Variansi Dua Jalan Sel Tak Sama

\begin{tabular}{|c|c|c|c|c|c|c|}
\hline Sumber & $I K$ & $d k$ & $R K$ & $F_{\text {hit }}$ & $F_{a}$ & Kep. Uji \\
\hline $\begin{array}{c}\text { Pendekatan } \\
\text { pembelajaran }(A)\end{array}$ & 18282,2266 & 2 & 9141,1133 & 36,1738 & 3,00 & $H_{0}$ ditolak \\
Kreativitas & 566,7497 & 2 & 283,3749 & 1,1214 & 3,00 & $H_{0}$ diterima \\
Belajar $(B)$ & 1785,5428 & 4 & 446,3858 & 1,766 & 2,37 & $H_{0}$ diterima \\
Interaksi $(A B)$ & 43771,30 & 169 & 259,0018 & - & - & - \\
Galat $(G)$ & 63340,7781 & 177 & - & - & - & - \\
Total & \multicolumn{7}{|c|}{} \\
\hline
\end{tabular}


Berdasarkan hasil analisis variansi dua jalan dengan sel tak sama, dengan taraf signifikansi 0,05 diperoleh sebagai berikut.

(a) Untuk nilai $F_{A}=36,1738>3,00=F_{0,05 ; 2 ; 169}$. Oleh karena itu, $H_{O A}$ ditolak. Hal ini berarti terdapat perbedaan pengaruh antar masing-masing kategori pendekatan pembelajaran terhadap prestasi belajar matematika. Dengan kata lain, terdapat perbedaan prestasi belajar matematika siswa yang dikenai pendekatan pembelajaran Reciprocal Teaching dengan Alat Peraga, Reciprocal Teaching, dan Konvensional. Setelah dilakukan uji lanjut antar baris pasca anava dua jalan sel tak sama dengan uji Scheffe'. Pada $H_{0}$ pertama, ditolak. Dengan memperhatikan rerata marginal, maka diperoleh simpulan bahwa prestasi belajar matematika siswa yang dikenai pembelajaran Reciprocal Teaching dengan Alat Peraga lebih baik dibandingkan dengan prestasi belajar matematika siswa yang dikenai pembelajaran Reciprocal Teaching. Hal ini sesuai dngan rumusan hipotesis. Pada $H_{0}$ kedua, ditolak. Dengan memperhatikan rerata marginal, maka diperoleh simpulan bahwa prestasi belajar matematika siswa yang dikenai pembelajaran Reciprocal Teaching dengan Alat Peraga lebih baik dibandingkan dengan prestasi belajar matematika siswa yang dikenai pembelajaran Konvensional. Hal ini sesuai dngan rumusan hipotesis. Pada $H_{0}$ ketiga, ditolak. memperhatikan rerata marginal, maka diperoleh simpulan bahwa prestasi belajar matematika siswa yang dikenai pembelajaran Reciprocal Teaching lebih baik dibandingkan dengan prestasi belajar matematika siswa yang dikenai pembelajaran Konvensional. Hasil dari penelitian ini sejalan dengan penelitian yang dilakukan oleh beberapa peneliti sebelumnya. Penelitian oleh Ghorbani, Gangeraj dan Alavi (2013) yang menyatakan bahwa efektivitas pembelajaran Reciprocal Teaching dapat meningkatkan prestasi belajar siswa. Ketika siswa menyadari pentingnya belajar dan gurupun mengimbangi dengan penggunaan pendekatan pembelajaran yang sesuai maka akan meningkatkan kinerja hasil belajar siswa itu sendiri. Begitu juga pada hasil penelitian Namaghi dan Shahhosseini (2011) yang mengatakan bahwa penggunaan pembelajaran Reciprocal Teaching dapat meningkatkan nilai yang maksimal karena pada pembelajaran ini guru mengajarkan keterampilan-keterampilan kognitif dengan menciptakan pengalaman belajar. Reciprocal Teaching dikembangkan untuk membantu guru menggunakana dialogdialog belajar dalam pembelajaran. Hasil penelitian Omari dan Weshah (2010) juga membuktikan bahwa pembelajaran Reciprocal Teaching dapat meningkatkan peringkat yang signifikan. Hal ini menyatakan bahwa pembelajaran Reciprocal Teaching dibandingkan pembelajaran Konvensional memiliki kontribusi yang berarti dalam pembelajaran. Sehingga rumusannya sesuai hipotesis. 
(b) Untuk nilai $F_{B}=1,1214<3,00=F_{0,05 ; 2 ; 169}$. Oleh karena itu, $H_{0 B}$ diterima. Hal ini berarti tidak terdapat perbedaan antar masing-masing kategori kreativitas terhadap prestasi belajar matematika antara siswa yang memiliki kreativitas tinggi, sedang, dan rendah. Hasil penelitian ini sama dengan hasil penelitian Anisatul Farida (2013) dimana tidak terdapat perbedaan pemahaman konsep matematika siswa pada kreativitas tinggi, sedang, dan rendah. Walaupun pada penelitian Farida terhadap pemahaman konsep namun tinjauannya sama yaitu pada kreativitas. Hasil penelitian Rini Utami (2011) juga menyatakan bahwa tidak terdapat perbedaan prestasi belajar matematika antar kelompok kreativitas tinggi, sedang, dan rendah. Adapun faktor yang menyebabkan tidak adanya perbedaan prestasi belajar matematika adalah karena dalam menyelesaikan soal-soal, para siswa pada umumnya melihat contoh soal yang diberikan sebelumnya. Kenyataan ini mengakibatkan tidak adanya perbedaan prestasi belajar pada siswa dengan kelompok kreativitas tinggi, sedang, dan rendah.

(c) Untuk nilai $F_{A B}=1,766<2,37=F_{0,05 ; 4 ; 169}$. Oleh karena itu, $H_{0 A B}$ diterima. Hal ini berarti tidak terdapat interaksi antara pendekatan pembelajaran dan kreativitas terhadap prestasi belajar matematika siswa. Karena tidak ada interaksi maka karakteristik perbedaan rataan prestasi belajar matematika antar sel dalam kolom yang sama akan sama dengan karakteristik perbedaan rataan marginal barisnya. Dengan demikian pada masing-masing kreativitas belajar tinggi, sedang, dan rendah penggunaan pendekatan pembelajaran Reciprocal Teaching dengan Alat Peraga menghasilkan prestasi belajar matematika yang lebih baik dibandingkan dengan penggunaan pendekatan pembelajaran Reciprocal Teaching maupun Konvensional dan pada pembelajaran Reciprocal Teaching menghasilkan prestasi belajar matematika yang lebih baik dibandingkan dengan Konvensional. Hal ini tidak sesuai dengan hipotesis penelitian. Selain itu, pada masing-masing pendekatan pembelajaran Reciprocal Teaching dengan Alat Peraga, Reciprocal Teaching, dan Konvensional prestasi belajar siswa dengan kreativitas belajar tinggi menghasilkan prestasi belajar yang lebih baik dari kreativitas belajar siswa sedang, prestasi belajar siswa dengan kreativitas belajar sedang menghasilkan prestasi belajar yang lebih baik dari kreativitas belajar siswa rendah, dan prestasi belajar siswa dengan kreativitas belajar tinggi menghasilkan prestasi belajar yang lebih baik dari kreativitas belajar siswa rendah. Hal ini tidak sesuai dengan hipotesis penelitian. 


\section{SIMPULAN DAN SARAN}

Simpulan hasil penelitian ini adalah sebagai berikut. (1) Siswa yang dikenai pendekatan pembelajaran Reciprocal Teaching dengan Alat Peraga mempunyai prestasi belajar matematika yang lebih baik dibandingkan siswa yang dikenai pendekatan pembelajaran Reciprocal Teaching dan Konvensional, siswa yang dikenai pendekatan pembelajaran Reciprocal Teaching mempunyai prestasi belajar matematika yang lebih baik dibandingkan siswa yang dikenai pembelajaran Konvensional. (2) Siswa dengan kreativitas tinggi, sedang, dan rendah mempunyai prestasi belajar matematika yang sama. (3) Pada masing-masing tingkatan kreativitas siswa, penggunaan pendekatan pembelajaran Reciprocal Teaching dengan Alat Peraga memberikan prestasi belajar lebih baik dibandingkan pendekatan pembelajaran Reciprocal Teaching maupun Konvensioanl dan pada setiap tingkatan kreativitas siswa penggunaan pendekatan pembelajaran Reciprocal Teaching memberikan prestasi belajar yang lebih baik dibanding menggunakan pembelajaran Konvensional. (4) Pada masing-masing pendekatan pembelajaran (Reciprocal Teaching dengan Alat Peraga, Reciprocal Teaching, dan Konvensional), prestasi belajar siswa dengan kreativitas belajar tinggi, sedang, dan rendah menghasilkan prestasi belajar yang sama.

Saran dari hasil penelitian ini adalah sebagai berikut. (1) Guru dan calon guru hendaknya memperhatikan adanya pemilihan pendekatan pembelajaran yang tepat dan inovatif berupa pendekatan pembelajaran yang peneliti gunakan dalam penelitian ini yaitu Reciprocal Teaching dengan Alat Peraga yang sesuai hasil penelitian dapat meningkatkan prestasi belajar matematika siswa. (2) Siswa diharapkan lebih aktif dalam kegiatan pembelajaran serta mengoptimalkan kreativitas yang ada dalam diri masingmasing sehingga prestasi belajar matematika dalam proses pembelajaran dapat tercapai. (3) Bagi calon peneliti lain dapat melakukan penelitian dengan tinjauan yang lain atau pendekatan yang sama tetapi pada materi yang berbeda disesuaikan dengan kebutuhan materi terhadap pendekatan pembelajaran.

\section{DAFTAR PUSTAKA}

Anisatul Farida. 2013. Eksperimentasi Pembelajaran Matematika Menggunakan Pendekatan Matematika Realistik dengan Metode Permainan Pasaran Terhadap Pemahaman Konsep Matematika Ditinjau dari Kreativitas Siswa SD di Kecamatan Banjarsari Kota Surakarta. Tesis S2. Program Pascasarjana UNS. Surakarta.

Cecep Kustandi, dkk. 2011. Media pembelajaran Manual dan digital. Bogor: Ghalia Indonesia. 
Ghorbani, R. M., Gangeraj, A. A. dan Alavi, Z. S. 2013. Reciprocal Teaching of Comprehension Strategies Improves EFL Learners' Writing Ability. Current Issues in Education. Vol. 16, Number 1, ISSN 1099-839X.

Hamzah B. Uno, dkk. 2011. Belajar Dengan Pendekatan PAILKEM. Jakarta: Bumi Aksara.

Namaghi, O. A. S. dan Shahhosseini, R. M. 2011. On the Effect of Reciprocal Teaching Strategy on EFL Learner's Reading Proficiency. Journal of Language Teaching and Reseach. Vol. 2, No. 6, pp. 1238-1243. ISSN 1798-4769.

Omari, A. H. dan Weshah, A. H. 2010. Using the Reciprocal Teaching Method by teachers at Jordanian Schools. European Journal of Social Sciences. Vol. 15, Number (1), hal. 26-39.

Rini Utami. (2011). Eksperimentasi Model Pembelajaran Berbasis Masalah dengan Langkah Penyelesaian Berdasarkan Polya dan Krulik-Rudnick Ditinjau dari Kreativitas Siswa. Tesis S2. Program Pascasarjana UNS. Surakarta.

Rusman. 2010. Model-Model Pembelajaran: Mengembangkan Profesionalisme Guru. Jakarta: PT Rajagrafindo Persada.

Slavin. 2005. Cooperative Learning: Theory and Practice. Bandung: Nusa Media.

Syaiful Sagala. 2011. Konsep dan Makna Pembelajaran. Bandung: Alfabeta.

Trianto. 2010. Mendesain Model Pembelajaran Inovatif-Progresif. Jakarta: Kencana.

Uyung Widi Rahayuningsih. 2009. Eksperimentasi Pembelajaran Matematika Dengan Menggunakan Alat Peraga Pada Pokok Bahasan Bangun Ruang Sisi Lengkung Terhadap Prestasi Belajar Matematika Ditinjau Dari Kreativitas Siswa-Siswa SMP Negeri Sukoharjo Tahun Ajaran 2008/2009. Tesis S2. Pascasarjana UNS. Surakarta. 